\title{
Attention to Sociotechnical Tinkering with Irrigation Infrastructure as a Way to Rethink Water Governance
}

\author{
Jeltsje Sanne Kemerink-Seyoum ${ }^{1,2, *}$, Tavengwa Chitata ${ }^{3,4}$, Carolina Domínguez Guzmán ${ }^{2}$, \\ Luis Miguel Silva-Novoa Sanchez ${ }^{5}$ and Margreet Z. Zwarteveen ${ }^{1,2}$ \\ 1 Integrated Water Systems and Governance Department, IHE Delft, Westvest 7, 2611 AX Delft, \\ The Netherlands \\ 2 Governance and Inclusive Development Group, University of Amsterdam, Postbus 15718, \\ 1001 NE Amsterdam, The Netherlands \\ 3 Department of Land and Water Resources Management, Midlands State University, Bag 9055, Gweru, \\ Zimbabwe \\ 4 Department of Geography, University of Sheffield, Western Bank, Sheffield S10 2TN, UK \\ 5 SILVANOVOA Consultores S.A.C., Jr. Tarapacá 131, Barranco, Lima 04, Peru \\ * Correspondence: j.kemerink@un-ihe.org
}

Received: 20 June 2019; Accepted: 29 July 2019; Published: 12 August 2019

check for updates

\begin{abstract}
Inspired by the proposal of political scientists and anthropologists to focus on "practice" as the smallest unit of analysis for understanding politics, as well as the renewed scholarly attention to materiality, this paper sets out to show that detailed ethnographic attention to processes and acts of sociotechnical tinkering provides a useful entry-point for understanding water governance. This is so methodologically, because infrastructural forms of tinkering are very visible, and therefore researchable, manifestations of agency and change in water governance. Attention to sociotechnical tinkering helps shift the basis for understanding water realities from official norms, designs and laws to everyday practices. This in turn allows questioning, rather than assuming, how expertise and agency are exercised and distributed in water governance, thereby also providing useful information for re-thinking water politics. In addition, by explicitly engaging with the contingency and capriciousness of actual water flows, a sociotechnical tinkering approach entails a much-needed re-appreciation of the materiality of water, infrastructure and other matter, a re-appreciation that extends to those who design, construct, operate and use water infrastructure.
\end{abstract}

Keywords: irrigation; smallholder farmers; water infrastructure; practices; materiality

\section{Introduction}

When walking through the upstream part of the Manyeredzi smallholder irrigation scheme in the south-east of Zimbabwe, we came across a twelve-year old boy who was using four siphons for each furrow to divert water from a tertiary canal to irrigate the crops on his plot. The official rule stipulates that a farmer can only use one siphon per furrow. That the boy nevertheless used more siphons was: "because it is hot, and it is my turn to fetch water for domestic use and prepare dinner at home, so I just want to finish early". He displayed little awareness of how his use of more water per unit of time than is allowed might cause water shortages for downstream farmers who rely on the same canal. Indeed, one of these farmers, an esteemed member of the irrigation management board, often struggles to get sufficient water to his field when it is his turn to irrigate. According to him, other farmers "... have to guard the division box and patrol the canal upstream when I am irrigating, to make sure upstream farmers are not readjusting the water flows". Even further downstream in the irrigation scheme, another farmer tried to irrigate her maize. She knows very well that the water she is 
formally entitled to is not enough for all the crops she planted to thrive in this hot climate. The canal from which she irrigates often runs empty in this section of the scheme. To get enough water, she dug her own additional small channels to capture both the water that is leaking from the poorly constructed canals upstream, as well as the run-off created by over-irrigation of upstream farmers. This run-off is partly the result of using more siphons per furrow than allowed. Her access to the water needed to irrigate her maize thus largely relies on the water "wasted" by others in the irrigation scheme. Yet, wasted water is not always a benefit, sometimes it is also a source of concern. She noted: "the crops ... turn yellowish because of too much water". In the absence of a drainage system to get rid of the accumulated water in this gently sloping part of the irrigation scheme, excess water risks cloaking the soils and damaging the roots of her crops, making it difficult to realize good yields. Yet, this same water allows a rainfed farmer located just outside the perimeter fence of the irrigation scheme to water his thirsty crops. He dug a ditch to his land to channel the water to his plot. With this hydraulic connection, he is actually expanding the command area of the irrigation scheme [1].

This vignette serves as an introduction to the theme of our paper, in which we present selected episodes of people in irrigation systems re-working the infrastructure to make water flow in the quantities, timing and direction that best suits them. By sharing these examples, we want to propose that empirical attention to the (often messy) details of the everyday sociotechnical arrangements that make water move provides a useful entry-point for a practice-based understanding of water governance. As some of us have argued in more detail elsewhere [2], a practice-based understanding usefully shifts thinking about water governance away from societal orderings that can be assumed (theorized) before an empirical investigation, and therefore, rationally designed and "fixed". Instead, a practice-based understanding takes societal orders, and the governance these assume or produce, as always in-the-making and inherently performative. Hence, rather than starting investigations by hypothesizing or positing the existence of a larger order, narrative or structure that is to be confirmed, refuted, illustrated or specified with empirical information, we propose the use of ethnographic material as a means of opening up ways to articulate, understand and create realities.

Our proposal is inspired by scholars who suggest that perhaps there is no larger structure or totality that holds reality together. Rather than helping uncover or expose larger structures or totalities, therefore, they propose using ethnographic methods to trace the multiple ways in which realities or worlds are constituted and enacted, accepting that there may be clashes, convergences or overlaps between these worlds, making them more or less durable or mobile [3-7]. Gibson-Graham [7] refer to such an ethnographic approach as "weak theory and thick description"; it aims to move beyond readymade narratives or big theories to explain processes of change, to instead focus on people's multiple socioecological lived experiences, everyday practices and roles, complex agencies and emotional relations. With ethnographic approach, we mean very detailed case studies for which data is collected during extensive fieldwork, primarily through qualitative data gathering approaches such as participant and artefact observations-in these cases in particular, the water infrastructure-semi-structured interviews, oral histories and/or focus group discussions. This data has, in our cases, been complemented and triangulated with existing data from (grey) literature, maps, (aerial) pictures, satellite images, databases, et cetera [1,8]. In bringing together the material for this paper, we are particularly interested in drawing attention to how infrastructure and the materiality of water co-shape institutions (rules) for sharing, distributing, using or indeed governing water.

\section{Theoretical and Methodological Considerations}

As the anecdote at the beginning of this paper suggests, the direction (in space and time), volume and quality of actual water flows arise from the sometimes contingent coming together of different people, water(s), infrastructure and much else. Following the "weak theory, thick description" adage [7], we do not intend to treat episodes or processes of sociotechnical tinkering as symptomatic of larger political or societal processes, nor do we present sociotechnical tinkering as a concept that can be used to generalize across contexts. Instead, our proposal to pay detailed attention to acts and processes of 
sociotechnical tinkering is an invitation to take differences seriously. These include differences between places (like offices and fields), people (like engineers and irrigators) and practices (like designing, constructing or irrigating). By doing this, we avoid mistaking similarities in design or function-of a technology or organizational setup, for instance-for broader similarities in designing or functioning, or in societal ordering. In other words, we hope that attention to sociotechnical tinkering will help recognize the multiple socio-political configurations that water infrastructures can be part of or help to change.

Even though they might use slightly different words and have different theoretical ambitions, there are many scholars of irrigation systems and irrigated farming who share our interest in changes in infrastructure as a useful entry-point for understanding irrigation management and governance, and water-related societal orders. Studies such as those by Coward [9], Wade [10], Chambers [11,12] van der Zaag [13], Bolding [14], Mollinga [15,16], Mosse [17], van der Zaag and Bolding [18], Rap and van der Zaag [19], Benouniche et al. [20], Méndez-Barrientos et al. [21], Kuper et al. [22] and Kooij et al. [23] all meticulously document the details of designing, constructing, and/or operating irrigation systems, thereby laying bare the gap between (design or institutional) norms and actual practice. In more recent years, scholars who study drinking water systems have also started paying attention to the role of infrastructure, including its form and materiality, in reinforcing, maintaining or contesting social relations of power [24-27]. These studies and reflections have provided important inspiration for our proposal for a theoretical-methodological approach to study actual processes of water governance.

Our proposal purposively resonates with two simultaneous and interconnected theoretical shifts within social sciences. The first is from the idealistic and normative to the actual and every-day. Inspired by a broader "return to practice" [28-30] in social and political sciences, this shift entails a plea for empirically anchoring understandings of behaviours and processes in descriptions of the actions of those actors involved in them. To bring practices into focus-referred to by Mol as "praxiography" [30]—an oft-used trick is to ontologically re-define "things" as verbs to shift attention from what "things" are to how they come into being or are enacted [30]. A precise documentation of everyday practices-which in water includes the practices of providing water services, of designing, operating and maintaining water systems, of protecting water sources and flows, of sharing water or water services, et cetera-creates room for acknowledging the messiness, creativity and contingencies in water governance processes, while also allowing a better appreciation of how water decisions and actions may be as much the outcome of pragmatic or tactical choices, as of strategic, power-laden ones. Scholars have proposed words like bricolage, braconage and tinkering to capture what happens between policy or design intentions and everyday realities [22,31-36]. A practice-based approach to water governance generates interesting challenges to existing conceptualizations of water authority and power by re-defining what counts as water knowledge, or in expanding who counts as knowledgeable about water: from only or mainly scientists and engineers to irrigators (and those they rely on for repairs and technical help) and local water user organizations $[19,20]$. A practice-based approach also usefully sheds doubts on the existence of identifiable centres of control and responsibility (formally appointed managers and operators) by allowing for and engaging with the possibility that actual water flows are the partly contingent outcome of interactions and negotiations between a range of human and more-than-human actors, only some of whom have formal responsibilities, rights and powers.

The second shift is the emerging interest in "materiality" in anthropology [37,38] (as well as in geography $[39,40])$. This interest stems from a desire to better appreciate how "natures" and "infrastructures' (or technologies) mediate, condition and co-shape what humans do and how societies evolve. Interest in materiality in part responds to a larger philosophical issue-inspired by feminist thinkers [41-43] — to rethink and undo the nature-culture (man-women, rationality-emotion, human-non-human, et cetera) binaries that have long provided the foundation for scientific endeavours. It also builds on a rapidly growing scholarship in Science and Technology Studies (STS) that is concerned with improving "sensibility to the messy practices of relationality and materiality of the world" [44]. One important theme in these conversations is the question of who or what to recognize as an actor 
(or as having agency). Here, Bruno Latour's definition of agency as "that what enables and shifts action or by which an action gets performed" [45], a definition that includes humans, objects, animals, "nature", ideas, organizations, and geographical arrangements [44] as possible actors is perhaps the most revolutionary and most widely discussed. While Latour's definition may cause discomfort, it is relevant to our argument because it invites thinking of agency beyond (human) intentionality [46], thereby creating space for recognizing how the "actions" or "behaviours" of water, technology or infrastructure co-shape the outcomes of water governance. Combining these two theoretical shifts critically relocates the problem of water governance from a distinct and identifiable social domain to a socio-material-natural one. It also resonates positively with conceptualizations of water governance as something that is never fully contained or controlled, or that is always partly experimental [39].

This paper is based on the realization that these shifts in thinking are not just theoretical, but also have important methodological implications. We advance the term socio-technical tinkering as a methodological approach for the research and analysis of practice-based water governance. The term refers to the human or watery interactions with infrastructure that deviate from plans and designs. These often form very visible, and therefore researchable, manifestations of change and agency. Sociotechnical tinkering helps not only to reveal how actual water flows often deviate from formal or public plans, technical designs and normative laws, but it also provides a chance to study where or what agency is, or where powers of authority and expertise are located. As an approach, sociotechnical tinkering involves explicitly tracing how actors constantly deploy their own categories and scales to sort the important from the insignificant and to determine how to act [47], showing how identities, roles or scales (sizes) are never stable but always defined in relation to other entities [48]. This diversifies thinking about power and politics, most notably by questioning the dichotomies of dominance-resistance, centre-margin, global-local, or transformation-adaptation [49]. As noted, studying sociotechnical tinkering also makes it possible to recognize the agency of water and other nonor more-than-humans, or at least to acknowledge how they co-move with others to shape water flows.

The overall argument and proposal of the paper is that detailed ethnographic attention to everyday practices of sociotechnical tinkering forms a useful entry-point for documenting and understanding the actual processes of water governance. To make this argument, we selected a number of empirical anecdotes, which we have categorized to show how a sociotechnical tinkering approach can lend support to (1) rethinking engineering expertise; (2) rethinking water politics; and (3) rethinking power and dominance. We drew our empirical examples from two case studies of smallholder irrigation schemes in Zimbabwe: the Manyeredzi smallholder irrigation scheme in the south, and the Nyanyadzi irrigation scheme in the east of the country (see Figure 1). Both irrigation schemes are deeply marked, although in different ways, by the historical and ongoing political struggles in Zimbabwe about agricultural land tenure between white settlers and so-called native African people. The Nyanyadzi irrigation scheme was constructed during the colonial era as part of an effort to dispossess the native African population from their fertile lands upstream in the catchment, and to resettle them on small pieces of marginal land downstream. The Manyeredzi smallholder irrigation scheme was constructed more recently in an attempt to grant farmers access to water, after being resettled on a piece of dry land adjacent to a conveyor canal a decade earlier. Both case studies, including the used methods and empirical data sets, are discussed in more detail elsewhere $[1,8]$. 


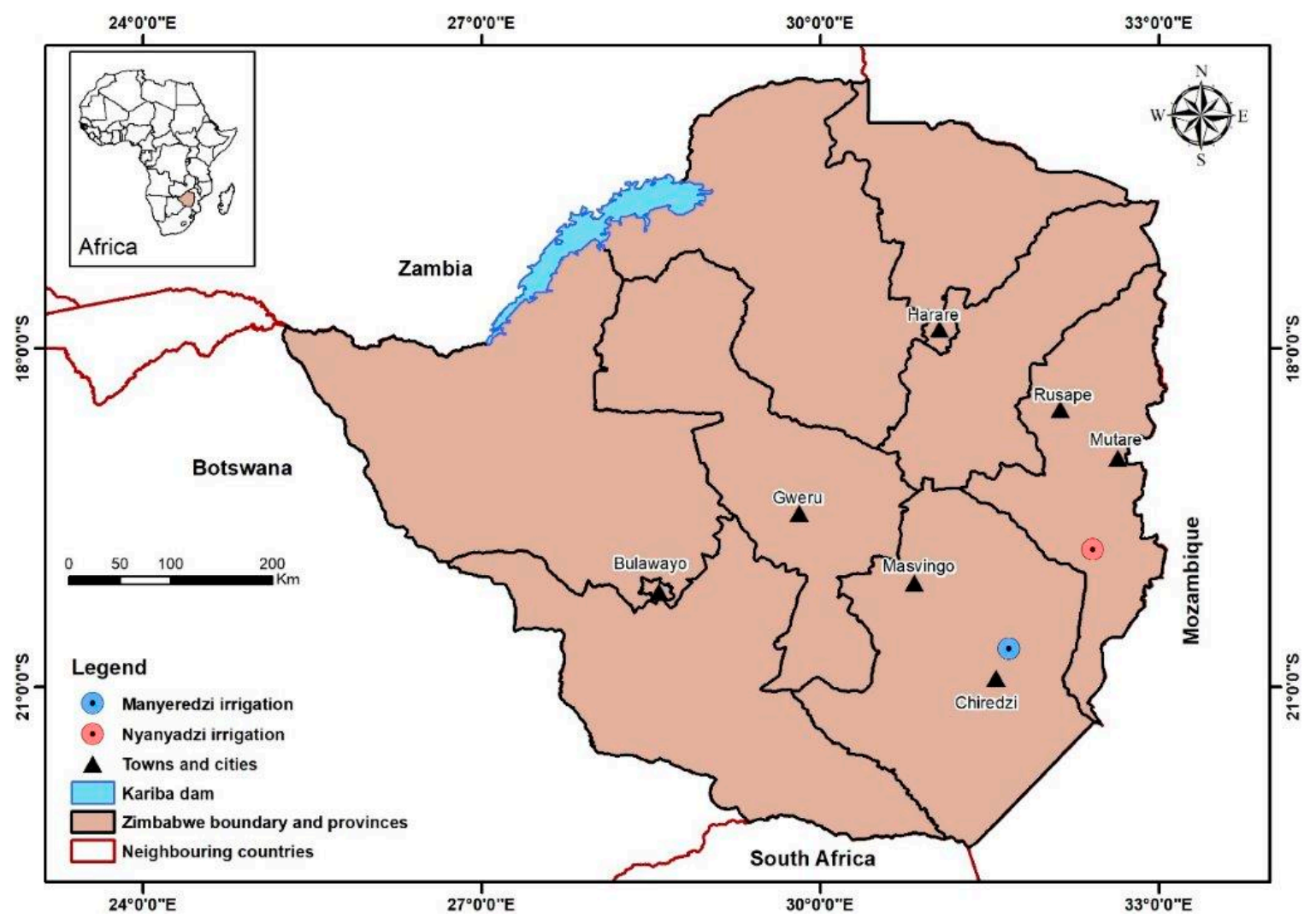

Figure 1. Location of the Manyeredzi smallholder irrigation scheme and the Nyanyadzi irrigation scheme.

\section{Rethinking Engineering Expertise}

An important observation from both case studies is that original or official designs or blueprints of the irrigation systems-those that are shelved in offices-provide a very inaccurate reference for understanding their actual lay-out, form and functioning. Both irrigators and engineers continuously make changes and adaptations to these designs, often in response to practical constraints. This starts during the construction of the system.

In the Manyeredzi smallholder irrigation scheme, the irrigation infrastructure was constructed in 2013 as part of the election campaign of the ruling party, who hoped to win farmers' votes by technically formalizing and facilitating their access to water from the conveyor canal. This canal was originally constructed to carry water to a downstream sugar cane estate that was previously owned by the colonial authorities and was later taken over by a foreign company. The smallholder farmers who cultivated land adjacent to this canal had settled there a decade earlier: they had been allocated the land as part of Mugabe's contentious land reform process. Even though the land was next to the conveyor canal, the newly settled farm families had not received official permission to make use of the canal water to irrigate their fields. Aspiring to also grow crops in the dry season, the farmers nevertheless started to draw water from the canal. They initially made use of siphons and buckets to do this, but later also engaged in acts of sabotage by puncturing the concrete canal structure.

A senior engineer working for the Zimbabwe National Water Authority referred to these acts of sabotage to explain where the idea for the 2013 smallholder system came from: "We did not have a choice, we had to give them (the farmers) water to protect the canal. They were destroying the conveyor canal by digging and putting holes in it, and we had to open offtakes to protect the canal" [1]. Thus the new system was explained as a strategy to stop farmers' acts of destruction and sabotage, which were destroying the conveyor canal. The new construction turned hitherto illegal abstractors into rightful irrigators: the new offtakes and the adjacent canals "cemented" and thereby legitimized an existing informal situation. 
Another engineer, who was involved in the design and construction of the irrigation scheme, explained his considerations and choices while designing the new offtake and irrigation canals. For him, the fact that farmers were already irrigating with the water from the conveyor canal mattered: "These farmers were already irrigating before we made proper designs and they knew what they were doing about their irrigation cycle, so I did not bother to calculate. In any case, it is not always guaranteed that farmers will follow the design ... they do not follow the design frequency and cycles anyway, they just irrigate" [1]. Even though the engineer knew that the smallholder farmers would mainly use the irrigation scheme to grow maize and vegetables for subsistence, he decided to use a standard design for the irrigation canals, which were dimensioned for irrigating sugar cane. This crop requires larger quantities of water and is less affected by undrained soils than the crops the farmers wanted to grow. He reasoned that, based on his experience of farmers tinkering with irrigation systems, his design choices would not matter that much so for his own convenience he picked a design he had recently used for another irrigation scheme.

Also, during the construction of the Manyeredzi offtake-which was built concurrently with thirteen other offtakes along the canal—pragmatic choices were made. For instance, an important consideration for the engineers, was that they wanted to finalize the work within the two-week period when the conveyor canal is annually emptied for maintenance purposes. Using this time slot would make their work a lot easier as it would avoid any additional effort (and time) to empty the canal. To make it possible to finalize the work in these two weeks, they altered the original design by choosing offtakes with a lower head, as these require less time to construct. The ability to quickly finalize construction was also expedient because of the political pressure they were facing from the ruling party, who wanted the job done before the upcoming general elections. The net result of constructing the new offtakes in this way was to lower the water carrying capacity of the conveyor canal, as water would now spill over the lower heads of the offtakes into the irrigation canals. This also reduced the volume of water flowing to the downstream sugar cane estate.

The irrigation engineers also experimented with the materiality of the system in other ways. When they calculated the concrete mixture to construct the canals, they used standard ratios of cement, sand, stone and water. However, the sand and stones purchased locally had different qualities than "standard" ones, which caused the quality of concrete in the first stretch of the secondary canal to be lower than expected. After the construction workers noticed this they started, with the consent of the engineers, to increase the quantity of cement in the concrete mixture used for lining the remaining canals. As the bill of quantities could no longer be adjusted at this point in the process, the engineers had to shorten the total length of both the secondary and tertiary canals to ensure they would not run out of concrete before "completing" the work. The net result of these changes was that the secondary canals in the upstream part of the irrigation scheme leaked, and that the lay-out of the tertiary canals in the lower part of the scheme was different than originally designed.

Lastly, and again, contrary to the original plans, the engineers decided not to level the fields due to budget constraints. This meant that some tertiary canals were below field level, making irrigation difficult.

These aberrations and adaptations to the original design caused the system to perform differently than expected and planned. This, in turn, placed demands on the creativity of farmers, forcing them to make further adaptations and changes to get water to their plots [1].

Thus, documenting the everyday practices of irrigation engineers during the construction of the Manyeredzi irrigation scheme draws attention to how these engineers-who in theory, develop and follow blueprint designs based on knowable and rational considerations (combining the scientific laws of hydraulics with insights from meteorology, agronomy and soil science to match crop water requirements with actual water made available through canal infrastructure)-became bricoleurs. That is, in their day-to-day work, in their interaction with construction workers and in direct consultation with (future) operators and irrigators, engineers are heavily involved in all kinds of sociotechnical tinkering and making-do, mainly in response to a range of logistical and practical considerations 
(funding, time, available materials and equipment). Also, they often have to experiment because precise data about meteorology, soils, etc. may not available. Engineers thus modify and often simplify and experiment with original designs to (gradually) make them fit various needs and contexts. The Manyeredzi episode is not unique in this: recent studies in Morocco [20,22,50] and elsewhere [51,52] provide telling empirical details of how "making systems work" (or making waters flow) hinges on the ability of engineers to creatively adapt and modify standard designs to make those suit specific social, financial, political, and ecological circumstances as well as farmers' demands and needs.

Recognizing that this is so may not come easily to engineers themselves, who may prefer to adhere to a mathematical-rationalist image of their profession and designs [53,54]. This is what Paul Pascon, a renowned French sociologist who lived and worked in Morocco in the second half of the 20th century and who was involved in training agricultural engineers, concluded. Referring to Lévi-Strauss's famous distinction between the "bricoleur" and the "engineer" as representing two contrasting modes of thought, Pascon noted that when confronted with messy field realities the engineer has two options. Either they adapts their ideal and scholarly models to field realities, and engage in a process of sociotechnical tinkering, which can also be termed bricolage, or they continue to stick to official design procedures and norms. When choosing the first option, that is, making do with whatever is available locally and designing systems that work, engineers and their designs may be well regarded and respected by irrigators, but much less so by their peers, i.e., the engineering community. The second option will have the reverse effect: it will create sophisticated systems that do not work, but garner respect among peers [53,55].

The Manyeredzi example suggests that the creative day-to-day activities of engineers rarely live up to the professional ideal of rational design. While some engineers may uphold this ideal in official accounts of what they do (perhaps to protect commercial, reputational or political interests), and while this is how engineering is often taught to students, attention to sociotechnical tinkering reveals that creativity and the ability to engage in bricolage are as, or more important to ensure that engineers and their designs (or constructions) are more successful than strict adherence to norms and blueprints-see also [56].

\section{Rethinking Politics}

Scholarly attempts to understand the relationships between politics and infrastructure tend to focus on one of aspect (say politics) and then focus research efforts on tracing how the other element (in this case infrastructure) either reflects the first or is co-shaped by it. Hence, Jensen and Morita claim that studies of infrastructure ... "often rely on rather stabilized concepts of the political. Infrastructures, that is, tend to be seen as giving material form to an (often neoliberal) politics, the characteristics of which, rather than questioned, are often taken for granted." [39]. Conversely, Tiwale et al. [27], drawing on the work of such scholars as Anand [25,57] and Meehan [24], note that although social scientists and geographers call for exposing and understanding the political work that technologies and infrastructures do, they often display a rather superficial treatment of technology, seeing it as "fixed material artefacts" that reflect or channel power in hardware, or as "the material substrates underlying social action" [39]. Technology and infrastructure itself, then tend to remain outside of what is changed, challenged and transformed through political actions and struggles. For this section, we selected an example that demonstrates that attention to processes and acts of sociotechnical tinkering supports thinking about the interactions between politics and infrastructure as mutually shaping each other in dynamically contingent and experimental ways. This is because such attention destabilizes infrastructure as well as politics: it allows us to open the black-box of technology, which also helps to unravel politics. Instead of neat sequential phases from design and construction to operation and use, attention to sociotechnical tinkering reveals that the form and functionality of water infrastructures are constantly experimented with and renegotiated among diverse groups of actors $[1,8,20,50,51,58]$ who operate and adjust their actions and decisions to the (re-)actions of nonor more-than-human actors, for example, water, silt, cement, stones, algae, weeds, et cetera. In other 
words, water infrastructures are hardly ever complete or fully closed, but "always becoming". They are best conceptualized as open-ended experimental systems, the outcomes of which are differently configured practical ontologies, which in turn give form to culture, society, and politics [59].

The "modernization" of the Nyanyadzi irrigation scheme by the colonial government in the late 1950s provides a nice case to articulate such a conceptualization. This irrigation scheme, founded in the early 1930s, originally extracted water from a weir in the downstream part of a relatively small catchment, which was conveyed by a gravity system of canals and gates to the fields. An appointed water operator opened and closed the gates to direct the water flow to the different canals, and the farmers collectively cleaned the canals after each rainy season. The water supply in the system diminished during the dry season and gradually became affected by increased water abstraction upstream, limiting the productivity of the irrigation scheme. The colonial government had the intention to settle as many native Africans as possible in the area near the irrigation scheme to free up the more fertile hinterland for white settlers. They also aimed for the native African population to be self-reliant and intended that the scheme would provide the basis for their subsistence, so that they would not become a burden for the government. Thus, modernizing the infrastructure was mainly aimed at increasing the water availability in the system to accommodate additional smallholder farmers in the scheme. This modernization entailed the instalment of diesel-, and later, electrically-generated pumps that were equipped with devices to measure and monitor water abstractions from the larger, nearby Nyanyadzi River. The water was pumped to an overnight storage reservoir constructed directly downstream of the first irrigation block. This meant that this block would continue to rely on the water abstracted from the old weir, while the three other irrigation blocks in the tail-end of the system could use the "new" water through a network of secondary and tertiary canals. For a while this irrigation scheme flourished. From the 1960s onwards, it even contributed to the production of maize for the national market. However, as more Africans were settled into the scheme and plots were sub-divided among younger generations, the plot sizes decreased and farmers could no longer produce beyond subsistence [14].

Because of its particular infrastructural design, the Nyanyadzi irrigation scheme constructed by the colonial government made it relatively easy for the post-colonial government to enforce the payment of water fees; the quantities of water pumped to the irrigation scheme were known thanks to the measuring devices, which allowed water bills to be calculated and justified. Yet, precisely because fees could be levied, the cost of accessing water in this irrigation system became considerably higher compared to elsewhere in the catchment, where monitoring of water uses and abstractions is more complicated and flows of water are more difficult to trace. By 2011, the farmers in the irrigation scheme had accumulated a collective debt of US $\$ 45,000$ for unpaid water and electricity bills. Pending the outstanding payment, the public electricity utility simply switched off the engines. Water was no longer distributed in the scheme, with the exception of the most upstream section, which still received intermittent water from the original weir in the river by gravity. According to many farmers, switching off the engines was a politically motivated choice, because (according to them) the government considered that this irrigation scheme was affiliated to the opposition. Their suspicion seemed to be confirmed when the ruling party promised that they would cancel the farmers' debt upon their victory in the presidential elections in 2013.

The farmers were unable survive without a harvest, thus switching off the pumps forced many of them to abandon their land and seek ways of making a livelihood elsewhere. The ones who stayed behind had no other option but to practice rainfed agriculture in the irrigation scheme, which yielded barely enough for subsistence. Allies of the ruling party gradually took over the vacated land in the irrigation scheme. They bought up larger plots, outsourcing the work to labourers or agricultural businesses. As one of the old farmers explained: "Worrisome is the fact that the same government just moves in on our ancestral land ... with their ... friends and business partners without any excuse or consultation, yet on the other hand wants us to pay for water they did not even make" [60]. The ruling party kept their election promise and cancelled the debt after they won the general elections. Since 
2014, the water is flowing again in the irrigation scheme. Yet, water operators now complain about intimidation and corruption by the new landholders, the allies of the ruling party. They either demand more water or categorically refuse to pay. One of the operators explains: "the laws are there but this issue of (the ruling party) is making it difficult to reprimand offenders". Attempts by the smallholder farmers to return to the land in the irrigation scheme and to reuse the infrastructure they collectively maintained have so far been unsuccessful [8].

This case shows that a similar piece of water infrastructure is capable of assembling as well as dispersing people, first and foremost depending on how it establishes or changes hydraulic property relations-which itself is a process that is often, at least partly, motivated by (state and party) politics. Hydraulic property is a concept coined by Coward [61,62] to draw attention to how the management of irrigation systems-interconnected sets of rules about responsibilities and rights that determine who gets how much water, when, and at what cost-is partly established, arranged, and enacted through irrigation infrastructure (weirs, canals, division works). Coward used the concept to denote how people establish and maintain rights to use the irrigation system (and the water that it conveys) through their investments of labour, materials, and capital in the construction and maintenance $[61,63,64]$ of the infrastructure, thus, drawing attention to infrastructural development as a property-creating process. Combining Coward's insight with our focus on processes and acts of sociotechnical tinkering highlights how hydraulic property can be conceived of as a never-complete process, with societal (including political) and infrastructural modifications co-shaping each other to produce emergent spatial and temporal configurations, as well as socio-political relations of water access and ownership.

Thinking of infrastructure as always in-the-making creates the conceptual space to recognize that water infrastructure itself is never intrinsically or fully constitutive or disruptive of state power [17,24]; what it does depends on is how it (re-)aligns with others-humans and non-humans-and with the wider political-economic landscapes that it is part of. The infrastructure itself is affected by and thus changes in the process. In our case study, some of the smallholder farmers who left the scheme moved their agricultural activities upstream, where they started farming along the river (sometimes even inside the riverbed) using illegally abstracted water and unlined furrows. This form of irrigation is similar to that used before the colonial era. Here, access to water is cheaper and more reliable thanks to the less "sophisticated" form and function of the infrastructure. The farmers, individually or collectively, dig canals that convey enough water to meet the water demands of their crops. Even though they regularly clash with the authorities about these illegal abstractions and although their infrastructure is sometimes washed away by flash floods, some of them manage to irrigate areas up to 0.5 hectares and sell their surplus at local markets. So many farmers have engaged in these upstream farming activities that the amount of water abstracted has started to affect the quantity of water flowing into the downstream irrigation system, circumventing official water allocations (or indeed, challenging formal hydraulic property relations). As one farmer explains, "we now practice dryland agriculture in our irrigation scheme and the scheme has since relocated to the river" [8]. Thus, sociotechnical modifications also re-arrange social relations of property and power. In this case, state owned and controlled infrastructural power was undermined by relatively simple infrastructure including small earthen canals, which created alternative spaces of rule and authority.

Although this case illustrates how infrastructures represent a degree of materialization (and thus stabilization) of power and politics, however, detailed attention to sociotechnical tinkering suggests that this materialization or stabilization need not be full or complete. While the degree of "tinkerability" of different water infrastructures is likely to vary depending on intrinsic material properties, and while every infrastructures is to some extent tenacious (thus, the initial form and materiality matter), with most water infrastructures there is still room for manoeuvring, modification and adaptation, for tinkering or tampering [65]. As our cases show, the implication is that distributional outcomes are contingent and always partly escape control and prediction. As Jensen and Morita put it, " ... if infrastructures are conceived of as experimental systems that generate emergent practical ontologies, then the shape of politics and power is one of the outcomes of infrastructural experiments". With 
this they do not imply that these ontologies only relate to "practical issues" but rather refer to "... how worlds are concretely made, conjoined or transformed by the co-evolving relations of multiple agents; people, technologies, materials, spirits, ideas—or what have you". Jensen and Morita maintain that instead of " ... beginning from a position in the metaphysical clouds [66] an interest in practical ontologies thus entails a "theory of the visible" [67]" [39].

\section{Rethinking Power, Dominance and Agency}

The fact that acts of sociotechnical tinkering are happening cannot in itself be interpreted as signals of resistance or sabotage or strategies to circumvent or challenge existing relations of power. As Cleaver notes in a recent chapter, many interactions over water may not be instances of struggle or resistance, but rather of small-scale cooperation and accommodation. They may sometimes even consist of attempts by actors to be incorporated into unequal distribution systems [49]. With Ortner [68], Cleaver maintains that understanding the politics of water behaviours requires (among other things) more attention to the subjectivity—the intentions, desires, fears, projects—of the actors engaged in these behaviours. "[T]his would involve explicitly foregrounding the politically unnoticed and taken-for-granted elements of everyday water politics, encompassing the routinized as well as the exceptional" [49]. Our own examples show that the reasons why actors intervene and tinker with infrastructure are often practical or pragmatic in intention, emerging in response to a need to find a practical solution to a problem-at-hand; a seizing of available opportunities arising through the combination of heterogeneous elements [32]. Indeed, acts and processes of tinkering need not be intentionally political, even when they do have political (or distributional) outcomes or effects. Such acts and processes do nevertheless reveal that there is room for shifting and changing the interpretations and distributions that an infrastructural design—often in combination with other modes of discipline and control-tries to enforce or enact. Using this space, even when out of sheer practical necessity, is a creative and micro-political act of agency.

Hence, it would be possible to interpret the construction of the Manyeredzi smallholder irrigation scheme as an attempt by farmers to redress a historical process of exclusion and marginalisation. Farmers' acts of tampering with the conveyance canal could be read as a rather forceful appropriation, in which the resettled smallholder farmers on the land adjacent to the canal literally took over the canal by damaging and puncturing its concrete structure. Yet, farmers themselves refer to these actions as inspired by the very practical need for water to make a living, with the geographical proximity of the canal creating the opportunity to actually access it. Few, if any, of them make mention of a desire to challenge water distribution injustices stemming from hierarchical power relations between them and agro-businesses, or between them and their autocratic government. In this particular case, what is interesting is how initial acts of what could be considered as stealing and sabotage gradually became accepted and normalized, partly also through their incorporation in infrastructure.

Also, the decision of the engineers to lower the head of the offtake of the Manyeredzi irrigation scheme, resulting in reducing the water flow in the conveyor canal supplying water to the downstream sugar cane estate, was not initially a politically strategic act, but more a pragmatic response to the political pressure they experienced. As one engineer explained: "we are not immune to political pressure, in this case, the pressure from politicians has pushed us to deviate from the service we aim to give to our clientele. The only good thing is: politicians will not point fingers at us if we do as they command, but not when we do otherwise". The ways in which people justify their own acts of sociotechnical tinkering, as well as how their actions are assessed by others within a particular normative configuration, are important elements for understanding how a tinkered material infrastructure helps create a "new"' normative environment.

Based on their own accounts, it is clear that the acts of sociotechnical tinkering that some smallholder farmers of the Manyeredzi irrigation scheme engaged in once the system was constructed, have a more strategic and protest-like character. The farmers' continued destruction of the conveyor canal, even after the offtakes were constructed, seriously jeopardized the water flow to the downstream 
sugar estate. As an official of the Zimbabwean Water Authority explains: "We thought that by opening offtakes we would solve the problem of illegal abstractions of water from the conveyance canal. Yes, it helped for a short while, but it is on the rise again, and it even gets worse in drought years". The reason farmers gave for their small acts of sabotage was that they objected to the limited command area of the new irrigation scheme. They were also unhappy with the water fees they were now expected to pay. Reflecting on the distrust between the farmers and the authorities, a farmer explained: "I think the [authorities are] stealing from us because I do not believe that we were using that much water ... I always believe that this [irrigation scheme] was a way to force us to reduce the area under irrigation" [1].

Distrust in and disagreement with the authorities is also what motivated the farmers in the Nyanyadzi irrigation scheme to refuse to pay for water. As one farmer explained: "the message of the government is to always pay, without explaining what the money is for. They forget that the river is ours. Had it been they had put a dam on the Nyanyadzi River, we would understand what the money is for". However, when going beyond their political rhetoric and prompting farmers to reflect on the intentions behind their actions revealed that acts of sociotechnical tinkering were also inspired by very pragmatic considerations - the need to make a living. Many of them accepted and accommodated the rules imposed on them, rather than contesting and resisting. With harvests barely meeting subsistence needs for the past five years, many farmers were simply not able to pay water fees. Moreover, as a farmer commented: "even if we pay, when the water comes it will not reach our plots". Hence, the farmers accepted the need to rely on sporadic rainfall and changed their cropping pattern to grow more drought resistant crops like millet, sorghum and groundnuts inside the once relatively productive irrigation scheme [61]. Likewise, the smallholder farmers who decided to leave their land and infrastructure behind to move upstream and grow crops along the river did not do so purely to oppose or resist government control. They simply went back to a traditional practice in response to the challenges they experienced in their everyday life.

We could provide many more empirical anecdotes to show how attention to acts and processes of sociotechnical tinkering fuels and supports a conceptualization of infrastructures (and more widely of water governance) as open-ended experimental systems that generate emergent practical ontologies. These "hold the potential capacity to do such diverse things as making new forms of sociality, remaking landscapes, defining novel forms of politics, reorienting agency, and reconfiguring subjects and objects, possibly all at once." [39]. Such a conceptualization draws attention to the cracks and fissures that always exist between ideal norms as expressed in infrastructural designs (or formal rules for operation and management) and the actual practices of engineers, construction workers, operators, irrigators, extension officers and politicians. To match the changing needs and demands of users and operators, irrigation systems require continuous work. Also water, silt, weeds, people and much else 'respond to' and continuously change what the systems does and where water flows, in turn prompting reactions from others. Deviations from the ideal may also stem from the fact that distributing water is only one of many social and political activities that irrigation actors engage in, with their irrigation identities also being only one of a range of possible identities. Multiple activities and identities seldom neatly converge and coalesce into the unified whole required for stabilizing infrastructure, or for establishing the firm grounds needed for strategic oppositional actions. Their existence therefore prompts the need to replace definitions of agency in terms of "resistance" versus "domination" [67] with definitions that acknowledge and account for how people's individual and collective ability to act emerges from how they are contingently and dynamically embedded in and socio-materially connected to others-humans and non-humans (for examples of situated definitions of agency, see $[69,70]$ ).

\section{Discussion and Conclusions}

"Sometimes it is hard to remember that it remains important to embrace situated technical projects and their people. They are not the enemy; they can do many important things for staying with the trouble and for making generative oddkin" [71]. 
Taking inspiration from the current theoretical interest in practice and the (renewed) scholarly attention to materiality, in this paper, we proposed sociotechnical tinkering as useful methodological approach for a practice-based understanding of water governance. This is so because infrastructural forms of tinkering create very visible manifestations of agency and change. These are potential political spaces and rallying points through which negotiations and interactions about water and its distributions become manifest, and therefore researchable. Detailed ethnographic attention to sociotechnical tinkering provides a sound empirical base from which to reconsider and destabilize theorizations of the links between politics, power and infrastructure. In particular, the shifting of the empirical basis for understanding irrigation realities from official norms, designs and laws to the everyday provides a useful challenge to those theories that assume, rather than question, how expertise, politics and agency are exercised and distributed in resource governance.

Attention to mundane quotidian acts of sociotechnical tinkering sheds an interesting light on the powers and authority of engineers by drawing attention to the creativity and making-do character of many of their choices and actions. While some may fear that such attention will damage their professional reputation, which traditionally rests on their superior ability to rationally calculate and control water flows, another and more positive way of looking at it is that it leads to a better appreciation of what engineers actually do in their day-to-day work. Indeed, if engineers' ability to creatively tinker more explicitly becomes part of how they are appraised and respected, they will also be encouraged to become even better at it. The ability to tinker may for instance be included in engineering education, or in the ways that the performance of engineers is assessed and rewarded. Documenting acts and processes of sociotechnical tinkering also foreshadows the active intellectual and practical engagement of irrigators and others (operators, constructions workers, extension officers, et cetera), prompting a useful re-appreciation of their expertise, powers and agency.

We have mobilized empirical material to suggest that acts of tinkering with infrastructure in irrigation systems - acts that produce deviations from plans and designs-are the rule rather than the exception; water flows seldom follow designs or plans, but come about through often contingent dynamic interactions between infrastructures (materials), water, other objects, meanings and people. Attention to sociotechnical tinkering, whereby different forms of agency intertwine, sheds light on the cracks in larger structures of domination, and provides the opportunity for "forceful and fugitive" waters to assume different meanings and open up alternative development pathways to those envisioned and supported by "global" recipes or the powers-that-be. In our analytical perspective, these spaces are not just created and ripped open by human beings in their everyday dealings with water, but are also unlocked by non- or more-than-human objects, including water itself. Thus, by asking questions about the creation and stability of structures (e.g., designs, institutions, societal orders), sociotechnical tinkering provides empirical inspiration for grappling with the co-existence of multiple ways of making sense of and living with water.

The timing and volume of water flows are significantly co-shaped by the shape and size of water infrastructures, which form the porous, malleable conduits through which water trickles, transcends and escapes. Infrastructures-pipes, canals, flumes, sluices, division boxes, siphons et cetera-interact with such things as sand deposits, algae growth and riparian vegetation, to manipulate, obstruct, alter and redirect the direction, size and quality of water flows. Water flows also interact with water legislation and policies, which render uses and users of water visible (or not) and understandable in particular ways. The many dynamic spatial and temporal interactions between different forms of agency - which are difficult to fully comprehend, and predict-open up a range of spaces for sociotechnical tinkering, and also demonstrate that water-at least partly-exceeds politics [55].

To further develop the potential of sociotechnical tinkering as a methodology to analyse the politics of water governance calls for learning to distinguish between, or create multiple ways to categorize and theorize, the different societal-political projects that tinkering with infrastructure can be part of, help shape or bring into being-from accommodation and acceptance, via bricolage and braconage, to rejection, resistance and contestation (see [72] for an example of distinguishing between 
different forms of institutional bricolage). Such learning should combine the documentation of the intentions and justifications of people involved in processes of sociotechnical tinkering with an analysis of how these acts are assessed, normalized or circumscribed by others, explicitly and reflectively including the appreciation of those doing the documentation, categorization or theorization.

Author Contributions: Conceptualization, J.S.K.-S., T.C., C.D.G., L.M.S.-N.S., M.Z.Z.; methodology, J.S.K.-S., T.C., C.D.G., L.M.S.-N.S., M.Z.Z.; formal analysis, J.S.K.-S., T.C.; investigation, J.S.K.-S., T.C.; writing一original draft preparation, J.S.K.-S., T.C., M.Z.Z.; writing—review and editing, C.D.G., L.M.S.-N.S.; supervision, J.S.K.-S., M.Z.Z.

Funding: The work presented in this paper was funded by Directoraat-generaal Internationale Samenwerking (DGIS), IHE Delft and Nuffic.

Acknowledgments: The work presented in this paper was funded by Directoraat-generaal Internationale Samenwerking (DGIS), IHE Delft and Nuffic. We thank our interviewees in the case study areas for sharing their knowledge and opinions with us and we thank the anonymous reviewers of this journal for their constructive comments and suggestions that have helped to further improve the content of this paper. We would like to especially acknowledge the contribution of our former student Ndaka Chinguno, who collected part of the empirical data presented in this paper, who unfortunately passed away much too early in life.

Conflicts of Interest: The authors declare no conflict of interest.

\section{References}

1. Chitata, T. Understanding Agency of Water Infrastructure in Everyday Agricultural Water Politics: A Case of the Manjirenji Conveyance Canal, Zimbabwe. Master's Thesis, IHE Delft, Delft, The Netherlands, 2017.

2. Zwarteveen, M.Z.; Kemerink-Seyoum, J.S.; Kooy, M.; Evers, J.; Guerrero, T.A.; Batubara, B.; Batubara, A.; Boakye-Ansah, A.; Faber, S.; Faber, A.C.; et al. Engaging with the politics of water governance. Wiley Interdiscip. Rev. Water 2017, 4, e1245. [CrossRef]

3. Ramamurthy, P. Material Consumers, Fabricating Subjects: Perplexity, Global Connectivity Discourses, and Transnational Feminist Research. Cult. Anthropol. 2003, 18, 524-550. [CrossRef]

4. Bossenbroek, L.; Van der Ploeg, J.; Zwarteveen, M. Broken dreams? Youth experiences of agrarian change in Morocco's Saïss region. Cah. Agric. 2015, 24, 342-348. [CrossRef]

5. Domínguez Guzmán, C.; Verzijl, A.; Zwarteveen, M. Water footprints and 'pozas': Conversations about practices and knowledges of water efficiency. Water 2017, 9, 16. [CrossRef]

6. Gibson-Graham, J.K. A Postcapitalist Politics; University of Minnesota Press: Minneapolis, MN, USA, 2006.

7. Gibson-Graham, J.K. Rethinking the Economy with Thick Description and Weak Theory. Curr. Anthropol. 2014, 55, 147-153. [CrossRef]

8. Kemerink-Seyoum, J.; Chinguno, N.; Seyoum, S.; Ahlers, R.; Bolding, J.; van der Zaag, P. Jumping the water queue: Changing waterscapes under water reform processes in rural Zimbabwe. Water SA 2017, 43, 423-432. [CrossRef]

9. Coward, E.W., Jr. Irrigation and Agricultural Development in Asia: Perspectives from the Social Sciences; Cornell University Press: Ithaca, NY, USA, 1980.

10. Wade, R. The system of administrative and political corruption: Canal irrigation in South India. J. Dev. Stud. 1982, 18, 287-328. [CrossRef]

11. Chambers, R. Managing Canal Irrigation: Practical Analysis from South Asia; Cambridge University Press: Cambridge, UK, 1988.

12. Chambers, R. The origins and practice of participatory rural appraisal. World Dev. 1994, 22, 953-969. [CrossRef]

13. van der Zaag, P. Chicanery at the Canal: Changing Practice in Irrigation Management in Western Mexico. Ph.D. Thesis, Wageningen University, Wageningen, The Netherlands, 1992.

14. Bolding, J.A. In Hot Water. A Study on Sociotechnical Intervention Models and Practices of Water Use in Smallholder Agriculture, Nyanyadzi Catchment, Zimbabwe; Ponsen \& Looijen: Wageningen, The Netherlands, 2004.

15. Mollinga, P.P. On the waterfront: Water Distribution, Technology and Agrarian Change in a South Indian Canal Irrigation System. Ph.D. Thesis, Wageningen University, Wageningen, The Netherlands, 1998.

16. Mollinga, P.P. Water, politics and development: Framing a political sociology of water resources management. Water Altern. 2008, 1, 7-23. 
17. Mosse, D. Epilogue: The cultural politics of water-A comparative perspective. J. S. Afr. Stud. 2008, 34, 939-948. [CrossRef]

18. Zaag, P.; van der Bolding, J.A. Water governance in the Pungwe river basin: Institutional limits to the upscaling of hydraulic infrastructure. In Transboundary Water Governance in Southern Africa: Examining Underexplored Dimensions; Swatuk, L.A., Wirkus, L., Eds.; Nomos: Baden-Baden, Germany, 2009; pp. 163-178.

19. Rap, E.; van der Zaag, P. The pivotal role of canal operators in irrigation schemes. The case of the canalero. Irrig. Drain. 2012, 61, 436-448.

20. Benouniche, M.; Zwarteveen, M.; Kuper, M. Bricolage as innovation: Opening the black box of drip irrigation systems. Irrig. Drain. 2014, 63, 651-658. [CrossRef]

21. Méndez-Barrientos, L.E.; Kemerink, J.S.; Wester, P.; Molle, F. Commercial farmers'strategies to control water resources in South Africa: An empirical view of reform. Int. J. Water Resour. Dev. 2016. [CrossRef]

22. Kuper, M.; Benouniche, M.; Naouri, M.; Zwarteveen, M. "Bricolage" as an everyday practice of contestation of smallholders engaging with drip irrigation. In Drip Irrigation for Agriculture: Untold Stories of Efficiency, Innovation and Development; Venot, J.P.K., Zwarteveen, M., Eds.; Routledge: London, UK, 2017; pp. 256-265.

23. Kooij, S.; van der Kuper, M.; Zwarteveen, M.Z.; de Fraiture, C.M. A user-centred approach to irrigation performance: Drip irrigation in the Khrichfa area, Morocco. Water Int. 2017, 42, 794-809. [CrossRef]

24. Meehan, K.M. Tool-power: Water infrastructure as wellsprings of state power. Geoforum 2014, 57, $215-224$. [CrossRef]

25. Anand, N. Leaky states: Water audits, ignorance, and the politics of infrastructure. Public Cult. 2015, 27, 305-330. [CrossRef]

26. Furlong, K.; Carré, M.N.; Acevedo-Guerrero, T. Urban service provision: Insights from pragmatism and ethics. Environ. Plan. A Econ. Space 2017, 49, 2800-2812. [CrossRef]

27. Tiwale, S.; Rusca, M.; Zwarteveen, M. The power of pipes: Mapping urban water inequities through the material properties of networked water infrastructures: The case of Lilongwe, Malawi. Water Altern. 2018, 11, 314-335.

28. Bueger, C. Pathways to practice: Praxiography and international politics. Eur. Political Sci. Rev. 2014, 6, 383-406. [CrossRef]

29. Miettinen, R.; Samra-Fredericks, D.; Yanow, D. Re-turn to practice: An introductory essay. Organ. Stud. 2009, 30, 1309-1327. [CrossRef]

30. Mol, A. The Body Multiple: Ontology in Medical Practice; Duke University Press: Durham, NC, USA, 2002.

31. Levi-Strauss, C. The Savage Mind; University of Chicago Press: Chicago, IL, USA, 1966.

32. Certeau, M.D. The Practice of Everyday Life; University of California Press: Berkeley, CA, USA, 1984.

33. Cleaver, F. Reinventing institutions: Bricolage and the social embeddedness of natural resource management. Eur. J. Dev. Res. 2002, 14, 11-30. [CrossRef]

34. Behagel, J.H.; Arts, B.; Turnhout, E. Beyond argumentation: A practice-based approach to environmental policy. J. Environ. Policy Plan. 2017. [CrossRef]

35. Furlong, K.; Kooy, M. Worlding water supply: Thinking beyond the network in Jakarta. Int. J. Urban Reg. Res. 2017, 41, 888-903. [CrossRef]

36. Bersaglio, B.; Cleaver, F. Green grab by bricolage-The institutional workings of community conservancies in Kenya. Conserv. Soc. 2018, 16, 467-480. [CrossRef]

37. Larkin, B. The politics and poetics of infrastructure. Annu. Rev. Anthropol. 2013, 42, 327-343. [CrossRef]

38. Jensen, C.B.; Morita, A. Infrastructures as ontological experiments. Engag. Sci. Technol. Soc. 2015, 1, 81-87. [CrossRef]

39. Whatmore, S. Materialist returns: Practising cultural geography in and for a more-than-human world. Cult. Geogr. 2006, 13, 600-609. [CrossRef]

40. Anderson, B.; Wylie, J. On geography and materiality. Environ. Plan. A 2009, 41, 318-335. [CrossRef]

41. Scott, J.W. Gender: A Useful Category of Historical Analysis. Am. Hist. Rev. 1986, 91, 1053-1075. [CrossRef]

42. Haraway, D.J. Simians, Cyborgs and Women. The Reinvention of Nature; Free Association Books: London, UK, 1991.

43. Despret, V. What Would Animals Say If We Asked the Right Questions? University of Minnesota Press: Minneapolis, MN, USA, 2012.

44. Law, J. Actor network theory and material semiotics. In The New Blackwell Companion to Social Theory; Turner, B., Ed.; Blackwell Publishing Ltd.: West Sussex, UK, 2009; pp. 141-158. 
45. Latour, B. Reassembling the Social: An Introduction to Actor-Network-Theory; Oxford University Press: Oxford, UK, 2005.

46. Law, J.; Mol, A. The actor-enacted: Cumbrian sheep in 2001. In Material Agency: Towards a Non-Anthropocentric Approach; Knappett, C., Malafouris, L., Eds.; Springer: Dusseldorf, Germany, 2008; pp. 57-78.

47. Jensen, C.B. Infrastructural fractals: Revisiting the micro-macro distinction in social theory. Environ. Plan. D Soc. Space 2007, 25, 832-850. [CrossRef]

48. Callon, M. The sociology of an actor-network: The case of the electric vehicle. In Mapping the Dynamics of Science and Technology; Callon, M., Law, J., Rip, A., Eds.; Palgrave Macmillan: London, UK, 1986; pp. $19-34$.

49. Cleaver, F. Everyday Water Injustice and the Politics of Accommodation. In Water Justice; Vos, J., Boelens, R., Perreault, T., Eds.; Cambridge University Press: Cambridge, UK, 2018; pp. 246-258.

50. Van der Kooij, S.; Zwarteveen, M.; Kuper, M. The material of the social: The mutual shaping of institutions by irrigation technology and society in Seguia Khrichfa, Morocco. Int. J. Commons 2015, 9, 129-150. [CrossRef]

51. Kemerink-Seyoum, J.S.; Munyao, S.; Schwartz, K.; Ahlers, R.; van der Zaag, P. Why infrastructure still matters: Unravelling water reform processes in an uneven waterscape in rural Kenya. Int. J. Commons 2016, 10, 1055-1081. [CrossRef]

52. Boesveld, H. The practice of designing and adapting drip irrigation systems. In Drip Irrigation for Agriculture: Untold Stories of Efficiency, Innovation and Development; Venot, J.P.K., Zwarteveen, M., Eds.; Routledge: London, UK, 2017; pp. 54-67.

53. Benouniche, M.; Kuper, M.; Hammani, A.; Boesveld, H. Making the user visible: Analysing irrigation practices and farmers' logic to explain actual drip irrigation performance. Irrig. Sci. 2014, 32, 405-420. [CrossRef]

54. van den Belt, H. A dialectic inquiry in the world of drip irrigation. In Drip Irrigation for Agriculture: Untold Stories of Efficiency, Innovation and Development; Venot, J.P.K., Zwarteveen, M., Eds.; Routledge: London, UK, 2017; pp. 325-335.

55. Pascon, P. Le technicien entre les bavures et le bricolage. Hommes Terre Eaux 1973, 8, 5-9.

56. De Laet, M.; Mol, A. The Zimbabwe bush pump: Mechanics of a fluid technology. Soc. Stud. Sci. 2000, 30, 225-263. [CrossRef]

57. Anand, N. Pressure: The politechnics of water supply in Mumbai. Cult. Anthropol. 2011, 26, 542-564. [CrossRef]

58. Silva-Novoa, L.M.; Kemerink-Seyoum, J.S.; Zwarteveen, M.Z. Water infrastructure always in-the-making: Distributing water and authority through the water supply network in Moamba, Mozambique. Water 2019. (under review).

59. Pickering, A. Material culture and the dance of agency. In the Oxford Handbook of Material Culture Studies; Hicks, D., Beaudry, M.C., Eds.; Oxford University Press: Oxford, UK, 2010.

60. Chinguno, N. From paper to Practice: An Analysis of the Impact of the Water Reforms on the Water Use Practices in Nyanyadzi River Catchment, Zimbabwe. Master's Thesis, UNESCO-IHE, Delft, The Netherlands, 2012.

61. Coward, E.W., Jr. State and locality in Asian irrigation development: The property factor. In Irrigation Management in Developing Countries; Nobe, K.C., Sampath, R.K., Eds.; Westview Press: Boulder, CO, USA, 1986; pp. 491-508.

62. Coward, E.W., Jr.; Levine, G. Studies of farmer-managed irrigation systems: Ten years of cumulative knowledge and changing research priorities. In Proceedings of the Public Intervention in Farmer-Managed Irrigation Systems, Kathmandu, Nepal, 3-6 August 1987; pp. 1-21.

63. Gerbrandy, G.; Hoogendam, P. The materialization of water rights: Hydraulic property in the extension and rehabilitation of two irrigation systems in Bolivia. In Crops, People and Irrigation: Water Allocation Practices of Farmers and Engineers; Diemer, G., Huibers, F.P., Eds.; Intermediate Technology Publications: London, UK, 1996; pp. 53-72.

64. Mollinga, P.P. Canal irrigation and the hydrosocial cycle: The morphogenesis of contested water control in the Tungabhadra Left Bank Canal, South India. Geoforum 2014, 57, 192-204. [CrossRef]

65. Horst, L. Dilemmas of Water Division; International Water Management Institute: Colombo, Sri Lanka, 1998.

66. Lynch, M. Ontography: Investigating the Production of Things, Deflating Ontology. Soc. Stud. Sci. 2013, 43, 444-462. [CrossRef]

67. Pickering, A. Time and a Theory of the Visible. Hum. Stud. 1997, 20, 325-333. [CrossRef] 
68. Ortner, S.B. Resistance and the problem of ethnographic refusal. Comp. Stud. Soc. Hist. 1995, 37, $173-193$. [CrossRef]

69. Cleaver, F. Understanding agency in collective action. J. Hum. Dev. 2007, 8, 223-244. [CrossRef]

70. McNay, L. Agency and experience: Gender as a lived relation. Sociol. Rev. 2004, 52, 173-190. [CrossRef]

71. Haraway, D.J. Staying with the Trouble: Making Kin in the Chthulucene; Duke University Press: Durham, NC, USA, 2016.

72. De Koning, J. Reshaping Institutions: Bricolage Processes in Smallholder Forestry in the Amazon. Ph.D. Thesis, Wageningen University, Wageningen, The Netherlands, 2011.

(C) 2019 by the authors. Licensee MDPI, Basel, Switzerland. This article is an open access article distributed under the terms and conditions of the Creative Commons Attribution (CC BY) license (http://creativecommons.org/licenses/by/4.0/). 